\title{
BUSINESS
}

\section{Patent crunch pending}

\section{Drug makers are fighting a rear-guard action against patent laws that are before the US Congress. Meredith Wadman reports.}

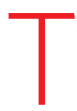
he biotechnology firm Alkermes in Cambridge, Massachusetts, has made a big bet on a simple idea: that patients with diabetes should be able to inhale, rather than inject, their insulin. Since the method was first described in 1997 (D. A. Edwards et al. Science 276, 1868-1872), the company has been developing it to allow large drug particles such as insulin to be delivered efficiently from a palm-sized inhaler. With its product now in the final stages of clinical trials, Alkermes — in partnership with drug maker Eli Lilly - has poured hundreds of millions of dollars into the venture.

But Alkermes has a problem on Capitol Hill: a package of reforms that the company, along with the rest of the biotechnology and pharmaceutical industries, says threatens to undermine its patents. The legislation passed the House of Representatives last month on a closer-than-expected vote; it may come to a Senate vote as soon as this month.

The Patent Reform Act of 2007 is predicated on the view that the US patent system has swung too far in favour of innovators, who are collecting outsized damage awards, to the detriment of sometimes innocent infringers. A commonly cited example is the $\$ 1.52$ billion levied against Microsoft in February by a jury in San Diego. The jury decided that the software giant had infringed two patents owned by Alcatel-Lucent, based in Paris, when it used the MP3 format in

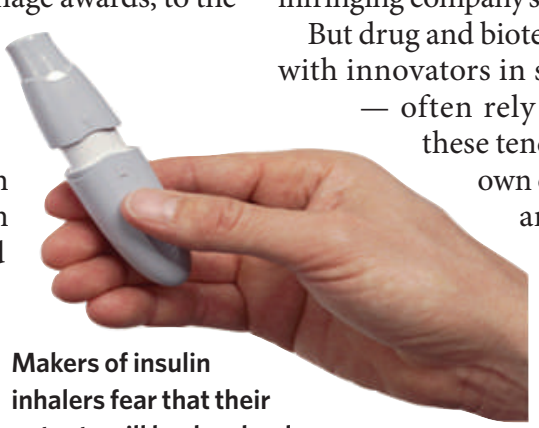
patents will be devalued. its Windows Media Player

software. (The verdict was overturned in August by a judge who contended that only one patent had been violated. A new trial to calculate the damages is awaited.)

\section{Damage limitation}

Most controversial, is the part of the reform that aims to reduce the amount of damages paid to firms when patents are infringed. It tells the courts to base damage awards on the economic value of the patented component that was infringed, not on the value of the entire product, as often happens under current law.

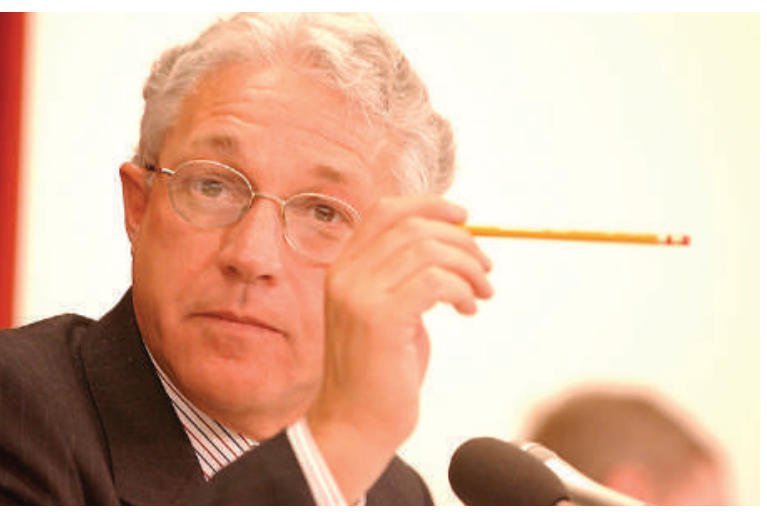

'You shouldn't have to throw the biotech industry under a bus to make life easier for the IT industry." - Jim Greenwood

It also instructs the courts to subtract out the economic value of all 'prior art' - that is, any publicly available information relevant to claims of originality - in the invention. That's music to the ears of the Apples and Microsofts of this world, whose products often rely on thousands of components, many of which have been patented by others - and sometimes without the infringing company's knowledge.

But drug and biotechnology firms - along with innovators in several other industries - often rely on fewer patents, and the tond the result of wn original work. Thus, they are more likely to sue for infringement than be sued. What's more, what look like minor advances on prior art in the drug industry can yield big advantages to patients. Consider, for instance, that neither insulin nor inhalers are new. So subtracting out prior art in the case of inhaled insulin could mean that Alkermes is left holding little or nothing in damages if it were to sue another firm for infringement, the company says.

Kathryn Biberstein, Alkermes' general counsel, warned the Senate judiciary committee back on 6 June that the legislation would discourage companies from developing products such as inhaled insulin by removing their incentives to do so.

The upshot is that the proposed change in damage calculations is strongly opposed by drug and biotech companies - along with big manufacturing firms such as Caterpillar and General Electric, who preside over patent estates that include everything from batteries to jet engines. They argue that the new approach will devalue their patents, their licences and ultimately their attractiveness to investors.

"If your protein is only $5 \%$ different from the preceding protein, which was prior art, you will receive pennies on the dollar," says Jim Greenwood, who heads the Biotechnology Industry Organization in Washington DC. "Under that kind of approach, it pays to infringe. And if it pays to infringe, people will no longer invest in companies with novel therapeutic patents."

"What Congress needs to do is improve the patent environment for all sectors of the American economy," says Greenwood. "You shouldn't have to throw the biotech industry under a bus to make life easier for the IT industry."

But the bill's supporters, including most of the finance and IT industries, counter that the changes are vital to curb damages that have run amok.

"I had three pieces of patent litigation in the late 1990s. Today I am defending 30," Mark Chandler, general counsel at the IT firm Cisco Systems in San Jose, California, told a forum at the American Enterprise Institute in Washington DC last month. "It's a huge increase in the amount of litigation and in expense."

\section{Lying in wait}

The majority of the cases he deals with today, Chandler says, are brought by 'patent trolls' who simply buy patents and then lie in wait for innocent companies to infringe them, adding no value or innovation themselves.

The proposed changes "bring patent law back to its focus of promoting innovation and not unfairly rewarding inventors at the expense of the economy", says Andy Cadel, the top intellectual-property lawyer at JPMorgan Chase, a financial-services firm based in New York.

The stark divide between those who make pills and those who make PCs brings considerable pressure to bear on senators with constituents in both camps, such as Joseph Biden (Democrat, Delaware) and Dianne Feinstein (Democrat, California). Those divided loyalties are just what the Biotechnology Industry Organization and its allies are counting on as they launch an all-out effort to block the bill from reaching a Senate vote. They face an uphill climb given the IT industry's funds and finesse - not to mention its friendly history with the Democrats who control Congress. 